\title{
GÜMÜŞHANE YEREL BASINI: TARIHSEL KÖKEN, SORUNLAR VE ÇÖZÜMLER
}

\begin{abstract}
Ali ÖZCAN ${ }^{1}$
öz

'Toplumsal hafıza' çalışması olarak görülen basın tarihi, toplumların geçmişinde yaşayan sosyal, siyasal ve ekonomik durumlara ilişkin detaylı bilgiler sunmaktadır. Basın tarihi, zengin içeriği ile araştırmacılar için önemli kaynakların başında gelmektedir. Basın tarihinin bir boyutunu oluşturan yerel basın, demokratikleşme, çeşitlilik ve temsil özelliğiyle önemli bir inceleme alanıdır. İki asırlık bir geçmişe sahip olan yerel basın konusunda Türkiye’de çeşitli iller ve önemli ilçeler/merkezler araştırmalara ev sahipliği yapmıştır. Bir asırlık bir geçmişe sahip olan Gümüşhane basın tarihi konusunda bugüne kadar kapsayıcı/bütüncül bir çalışma yapılmamıştır. $\mathrm{Bu}$ çalışmada, Gümüşhane yerel basınının Osmanlı'dan Cumhuriyete tarihsel serüveni ve bugünkü mevcut durumu incelenmiş̧tir. Tarihsel süreçte Gümüşhane'de kamu ve özel sektörün yayınlamış olduğu yerel gazeteler/dergilerin bibliyografik bir dökümü yapılacak, böylece bundan sonra yapılacak çalışmalar için bilimsel bir altyapı oluşturulacaktır. Çalışma kapsamında Gümüşhane özelinden hareketle yerel basının kendi yapısından ortaya çıkan ve dış kaynaklı sorunları da tartışılarak, çözüme dönük öneriler sunulmuştur. Yerel basın için bilgi ve iletişim teknolojilerinin sunmuş olduğu yeni nesil gazetecilik uygulamalarının hayata geçirilmesi bir çözüm önerisi olarak tartış1lmıştır.
\end{abstract}

Anahtar Kelimeler: Yerel Basın, Gümüşhane, Bilgi ve İletişim Teknolojileri

\section{GUMUSHANE LOCAL PRESS: HISTORICAL BACKGROUND, PROBLEMS AND SOLUTIONS}

\begin{abstract}
The history of the press, which is generally seen as the study of social memory, provides detailed information on the social, political and economic conditions of societies. The history of the press is one of the most crucial sources for researchers with its rich content. The local press, which constitutes a dimension of the history of the press, is an essential field of investigation in terms of democratization, diversity and representation. Having a history of two centuries in the local press several cities and major towns in Turkey / center has hosted the research. Gumushane, which has a history of a century, has not been involved in a comprehensive / holistic academic research until today. In this study, historical process of Gumushane local press from Ottoman to Republic and its present situation will be examined. In the historical process, a bibliographic breakdown of local newspapers / magazines published by the public and private sectors will be made in Gumushane, in doing so this study creates a scientific infrastructure for the further studies. Within the scope of the study, external issues arising from the structure of the local press, based on Gumushane, will also be discussed and suggestions for solution will be presented. Furthermore, the implementation of a new generation of journalism applications presented by information and communication technologies for the local press will be discussed as a solution proposal.
\end{abstract}

Keywords: Local Press, Gumushane. Information and Communication Technologies

${ }^{1}$ Dr. Öğr. Üyesi, Gümüşhane Üniversitesi Illetişim Fakültesi, aliozcan@gumushane.edu.tr ORCID ID: 0000-0001-2345-6789 


\section{Giriş}

İnsanı diğer bütün canlılardan ayıran iletişim olgusu, iletişim teknolojilerinin sunmuş olduğu imkânlar dâhilinde öncelikle yerel düzeyde ortaya çıkmıştır. Bu sebeple iletişim özünde yerel düzeyde başlayıp iletişim araçlarının sunmuş olduğu gelişmelerle birlikte bölgesel, ulusal, uluslararası bir boyuta taşınmıştır. Günümüz bilgi toplumunda iletişim olgusu küresel düzeyde gerçekleşmektedir. Haberin temel değerlerinden biri olarak 'nerede' sorusu coğrafi ya da kültürel anlamda yakınlığın önemine işaret etmektedir. İletişimin haberleşme formunda gerçekleştiği topluluklarda/toplumlarda bireyler doğaları gereği yakın çevrelerinde olan olaylardan daha fazla etkilenmekte ve ilgilerini/meraklarını bu yönde kullanmaktadır. Haberleşmeyi sağlayan en yaygın yöntemlerden biri olarak basın/gazetecilik de bireylerin bu ilgisine karşılık yerel düzeyde ortaya çıkmış, dolaşıma soktuğu içerikler/haberler de yerel konulardan oluşmuştur. Bu nedenle basın/gazetecilik özünde yerel olarak başlamıştır. Günümüzde yerel basın üzerine yapılan tanımlamalar mekânsal ve toplumsal olmak üzere iki boyutlu tartışılmaktadır. Mekânsal yerellikte coğrafi alan; toplumsal yerellikte ise paylaşılan değerler ve ortak kültürel özellikler/aidiyetler yerelliğin kapsamını belirlemektedir. Yerel kelimesiyle içeriksel açıdan bir yöreye ilişkin, coğrafi sınırlılık açısından da belli bir bölgeyi kapsayan özellikler ön plana çıkmaktadır. Yerel basın ile hedef kitlesi olan okuyucusu arasındaki toplumsal ve coğrafi yakınlık yayının içeriğinin belirleyicisi olmaktadır. $\mathrm{Bu}$ da yayın sürecinde okuyucunun dikkate alındığını göstermektedir. Yerel basının bu yakınlığı karşısında ulusal ya da uluslararası basının ekonomik, siyasal ve ideolojik ilişkileri yayın sürecinin belirleyicisi olmaktadır. Bu nedenle ulusal ve uluslararası basının katılımcılığa ve çok sesliliğe imkan sunması, bütün görüş ve düşüncelerin özgürce açıklanmasına izin vermesi mümkün olmamaktadır. Buna karşın özellikle çok sesliliği sağlamak ve demokratik bir iletişim süreci inşa etmek açısından özünde taşıdığı özelliklerle yerel basın önemli bir görev icra etmektedir. Güçlü yerel basın her zaman demokrasinin bir güvencesi olarak alternatif iletişim ortamı oluşturmaktadır (Güreli, 1999: 11-12). Yerel basın için iletişim literatüründe 'alternatif gazetecilik' kavramsallaştırması mevcut medya hegemonyası dışında ve karşısında olana işaret etmektedir (Özer, 2012: 10). 
Demokratik toplumların işleyişinde böylesi önemli bir görev icra eden yerel basın ABD ve Avrupa ülkelerine nazaran Türkiye'de zayıf bir iletişim halkası olarak görülmektedir. ABD’nin önemli gazetelerinin isimlerinin şehir isimleri olması (Washington Post, Los Angeles Times, New York Times vb.) yerelliğin ne denli önemli olduğunu göstermektedir (Tunstall, 1996: 2). Avrupa ülkelerinde de yerel basın ulusal basına göre hem satış hem de etki bakımından iyi durumdadır. Üstelik yerel basın şehirlerin sembolü olarak takip edilmektedirler (Charon, 1992: 163). Türkiye'de ise yerel basının durumu ABD ve Avrupa ülkelerinin tam tersi bir görüntü sunmaktadir.

Katılımcı demokrasinin güvencesi olarak yerel basın konusunda yapılan çalışmalar ulusal basına göre cılız kalmaktadır. Bu çalışmanın nihai amaçlarından biri yerel basının tartışılmasıdır. Yerel basın konusunda yapılan çalışmalara bakıldığında daha çok şehir bölge basın tarihi ve gazete monografileri söz konusudur. Genellikle köklü bir geçmişe sahip büyük şehirlerin basın tarihi (Konya, Trabzon vb.) çalışma konusu olmuştur. Cumhuriyetle eşdeğer bir basın hareketliliğine sahip olan Gümüşhane basını konusunda bugüne kadar yapılan çalışmalar hem nicelik açısından hem de nitelik açısından yetersiz kalmıştır. Bu çalışmanın amacı Gümüşhane yerel basın tarihi konusunda kapsayıcı bir şekilde ele alarak geçmişten bugüne tarihsel serüvenini kayıt altına almak, mevcut durumunu analiz ederek geleceğe dönük projeksiyonların oluşmasına katkıda bulunmaktır. Çünkü içinde yaşadığımız bilgi toplumunda yerel basını iletişim teknolojileri merkezli aktör olarak konumlandırmak ayakta kalması için zorunluluk arz etmektedir. Bu noktadan hareketle özelde Gümüşhane olmak üzere genel olarak yerel basının iletişim teknoloji dolayımlı günümüz koşullarında ayakta kalma çabası, yaşadığı sorunları ve çözümü noktasında yeni bir bakış açısı olarak bilgi ve iletişim teknolojilerinin kullanımının rolü tartışılacaktır.

\section{Türkiye'de Yerel Basın}

Türk basın tarihinin başlangıcı aynı zamanda yerel basının ortaya çıkış sürecidir (Erinç, 2007: 108). Çünkü Osmanlı Devleti'nde ayrılıkçı hareketlere karşı bir 
önlem olarak hayata geçirilen Islahat Fermanı'nda yerel basın olgusu ilk kez gündeme getirilmiştir. Islahat Fermanı'nda yerel idare düzenlemesi ile hem yerel yönetimler hem de yerel basın birer kurumsal yapı olarak ortaya çıkmıştır (Ayhan, 2007: 287). Bu yüzden yerel yönetimler ile yerel basın ontolojik benzerliğe sahip (Yılmaz, 2004: 107), doğru orantılı bir ilişki içinde olmuştur. Taha Akyol, (1992: 99) Nezih Demirkent'in ‘yerel yönetimler güçlendikçe yerel basın güçlenecektir' sözüne atıfta bulunarak, "Bizde yerel sorunlarla ilgili bilinç güçlendikçe yerel yönetim güçlenecek, yerel yönetim güçlendikçe de yerel gazeteler güçlenecektir” diyerek, bu doğru orantıya dikkat çekmiştir.

Osmanlı'da basının ilk örnekleri 'vilayet gazeteleri' olmuştur. Ayrılıkçı hareketlere karşı merkezi yönetimin taşra/çevre üzerindeki etkinliğini sağlamak/korumak amacıyla yayınlanan vilayet gazeteleri, aynı zamanda merkez ve taşra arasındaki haberleşmede de etkin bir şekilde kullanılmıştır (Bakoğlu, 1998: 159). Haberleşmenin tarihine bakıldığında da sözlü, yazılı ve basılı dönemde iktidarların bu gücü elinde bulundurmak, toplulukları/toplumu kontrol altına almak için haberleşmeyi denetledikleri görülecektir. Batıda haberleşmenin teknolojik altyapı gereksinimli bir şekilde gelişmesi (matbaa) bu alanda sermaye birikimini gerekli kılmıştır. Bu yüzden ticari kapitalizmin batı basının gelişiminde büyük etkisi olduğunu söylemek yerinde olacaktır. Batıda ilk gazetelerin özel teşebbüs tarafından yayınlanması da bu anlayışın kanıtı olarak gösterilmektedir (Alemdar, 1981: 99). Osmanlı'da ise haberleşme merkezi yönetimin tekelinde bulunduğu için doğal olarak gazeteciliğin gelişimi iktidarın inisiyatifine bağlı olarak gelişmiştir (Alkan, 1998: 66-67). Ayrılıkçı hareketlere karşı vilayet gazetelerinin yayınlanması bir merkezi yönetim propaganda biçimi olarak hayata geçirilmiştir. Vilayet gazetelerinin ilk örneği Tuna'da 1864 yılında Türkçe-Bulgarca yayınlanan 'Tuna' gazetesidir (Topuz, 2003: 382). Vilayet gazeteleri Türkçe'nin yanı sıra bölgede konuşulan dilde de yayın yapmıştır. Suriye'deki vuku bulan iç ayaklanmaları bastırmak için 1860'ta Beyrut'ta çıkmakta olan Hadikat al-Ahbaradlı Arapça gazete yerel yönetimin resmi sözcüsü olmuştur (Girgin, 2001: 85-86). Vilayet mektupçusu yönetiminde çıkan bu gazeteler (Koloğlu, 1994: 22) merkezi yönetimin işlevsel olarak kullanamaması nedeniyle zamanla özel sektöre devredilmiş, böylece Osmanlı'da ilk gazeteler vilayet matbaalarının 
bulunduğu şehirlerde yayınlanmaya başlamıştır. Katılımcı yönetim anlayışının bir sonucu olarak vilayet sistemine geçilmesiyle birlikte ortaya çıkan yerel basının zamanla üstlendiği görev üzerinden demokratik bir kurum olarak ifade edilmesi doğru olacaktır.

Türkiye'de yerel basın için daha çok 'Anadolu Basını' (Bodur, 1996: 42) ifadesi tercih edilmektedir. Böylesi bir isimlendirmenin temelinde yatan olay ise Kurtuluş Savaşı sürecinde basının tavrı olmuştur. İstanbul'da yayınlanan gazetelere karşı Milli Mücadeleyi destekleyen gazeteler Anadolu'da yayınlanan gazeteler olmuştur. Bu dönemde basın, Anadolu ve İstanbul yanlısı şeklinde ikiye ayrılmıştır (Tılıç, 1998: 79). Yerel basın Milli Mücadele'de üstlenmiş olduğu bu görev nedeniyle 'milletin müşterek sesi' (Uçar, 1997: 34) olarak görülmüştür. Mustafa Kemal de 'fazilet adaları' olarak adlandırdığı yerel basın için şu ifadeleri kullanmıştır: “Anadolu basını, Türkiye Cumhuriyeti'nin kuruluşunda harcı olan bir basındır. Bir anlamda yerel basın, Ulusal Kurtuluş Savaşı'nın 'gazi basını'dır’. Milli Mücadele'nin ardından tek parti döneminde basına yönelik kısıtlamalar yerel basını da etkilemiştir. Bulundukları bölgenin sorunlarını merkeze ulaştırmak yerine, merkezi yönetimin emirlerini taşraya ulaştırmakta kullanılmıştır (Alkan, 1998: 61). Bu süreç, tıpk1 Osmanlı' da basının ortaya çıkışı ve kendisine yüklenen misyonla benzerlik taşımıştır. 1946 yılı itibariyle çok partili yaşama geçiş yerel basına da hareketlilik getirmiştir. Alpay Kabacalı'ya göre (1998: 291) tüm Türkiye’yi saran demokrasi özlemi yerel basının canlanmasını da sağlamıştır.

27 Mayıs 1960 darbesi sonrası yerel basını ilgilendiren en önemli gelişmelerden biri 1961 yılında kabul edilen 195 sayılı Basın İlan Kurulu'nun (BİK) teşkiline ilişkin kanundur. Bu kanuna göre, daha önce keyfi olarak dağıtımı yapılan reklamların gazetelere verilmesi belli şartlara bağlanmış ve resmi ilan dağıtımının 'fikir ve içtihat farkı aranmaksızın' yapılacağı kararlaştırılmıştır. Devlet desteği bu konuda yerel gazeteler için büyük önem taşımaktadır. 1961 yılından beri devam eden resmi ilan uygulaması yerel basının ayakta kalmasını sağlamaktadır.

12 Eylül 1980 darbesi bütün toplumsal kurumlar gibi basını da olumsuz yönde etkilemiştir. Bu süreçte yaygın gazeteler gibi yerel gazetelere de sansür uygulanmış, bazıları kapatılmıştır. Konya' da yayımlanan Türkiye'de Yarın gazetesi 31 Mayıs 1981 
yılında kapatılmıştır. Bunun gibi diğer illerde de 12 Eylül döneminde yasaklanan ve kapatılan yerel gazeteler söz konusu olmuştur (Kuyucu, 2012: 19).

Günümüzde sayıları 2 binin üzerinde olan yerel gazetelerin önemli bir bölümü miras yoluyla babadan oğula kalan, matbaacılık işinin yanında yürütülen bir iş olarak görülmektedir. $\mathrm{Bu}$ nedenle yerel gazeteler teknolojik imkânlardan yeterince yararlanamamış, çok az sayıda kişinin çalıştığı ve tirajı da 100’lerle başlayıp 1000'lerle ifade edilen yayınlardır. Resmi ilan gelirleri ve matbaada yapılan farklı işlerle ayakta kalabilen bu gazeteler ayakta kalabilme mücadelesi vermektedir. Bazı yerel gazeteler ise kapanmamak için günübirlik yayın politikaları uygulayan, resmi ilanlarla birlikte seçim dönemleri doğrudan ve reklam aracılığıyla siyasal partilerden destek alan yayınlar olmuştur.

Gazetecilik yerel, bölgesel, ulusal ve uluslararası olarak adlandırılmaktadır. 'Yerel'in karşıtı olarak ülke geneline ulaşan gazeteler için 'ulusal' kavramının kullanılmasına dönük eleştiriler söz konusudur, ancak bu konu yeterince tartışılmamaktadır. Yerelin karşıtı olarak ulusal yerine -ulusalın karşılığı 'milli' olduğu için- 'yaygın gazeteler' ifadesi doğru olacaktır. Yerelin karşılığı olarak ulusal kullanımına bazı yerel gazete sahipleri de dikkat çekmektedir (Adalığlu, 1997: 47).

\section{Yerel Basının Sorunları}

Yerel basının sorunları Türkiye ölçeğinde yaygın basınla benzerlik taşımaktadır. Bunlar belli başlıklar altına toplandığında, kendi yapısından ve dış kaynaklı olarak iki başlıkta incelenebilir. Kendi yapısından kaynaklı sorunlara baktığımızda teknolojik imkânlardan yeterince faydalanılamaması, kalifiye eleman çalıştırılmaması, reklamlara fazlaca yer verilmesi ve halkın isteklerine cevap verilmemesi olmak üzere ekonomik, teknik ve altyapı, nitelikli işgücü ile idari yapılanmayla ilgili konulardır (Kahraman, 1997: 85-87). Dış kaynaklı sorunlar ise siyasal yönetim anlayışı, gazete okuma oranlarının düşük olması, düşük tirajlar yerel basının gelişmesini engelleyen temel faktörler olarak yaygın gazeteler için de geçerlilik taşımaktadır (Erdoğan, 2007: 41). Bu sorunların temelinde yatan en önemli nedenin Batı'ya kıyasla Türk basınının çok derin bir geçmişe sahip olmaması gösterilmektedir (Çakır ve diğerleri, 2009: 2). 
Sermaye yetersizliği yerel basının ekonomik sorunlarının başında gelmektedir (Demirkent, 1999: 21). Gazete satışı ile ilan ve reklam olmak üzere iki kalemde geliri olan gazetelerin tirajları düşük olduğu için satıştan ve reklam, ilan gelirlerinden yeterince faydalanamadığı görülmektedir. Günümüzde yerel basın için en önemli gelir BİK tarafından resmi ilan karşılığı sağlanan destektir. BİK tarafından verilen resmi ilan ve reklam destekleri ise geçmişe oranla günümüzde daha eşit bir şekilde dağıtılmaktadır. Geçmişte yaygın gazeteler (İstanbul merkezli gazeteler) BİK ilan gelirlerinin neredeyse tamamına yakınını alırken günümüzde Anadolu'da yayınlanan gazetelerin destekten aldığı pay artırılmıştır. Buna rağmen yine de yaygın ve yerel gazetelerin resmi ilan ve desteklerden aldığı pay orantısızdır.

BİK'in kuruluşunun ardından 2000'lere kadar İstanbul'un resmi ilan ve reklamlardan aldığı pay yüzde 90 üzeriyken, 2005 'ten itibaren BİK'in yeni şubelerinin açılmasıyla birlikte dağıtımı yapılan ilanların oranı da ister istemez yerel basın lehine iyileşmiştir. 2013 yılında İstanbul'un resmi ilan ve reklamlardan aldığı pay yüzde 65'lere kadar düşmüştür. Yerel gazetelerin tirajlarının düşük olması resmi ilan dışında özel sektörden reklam almasını da etkilemektedir. Doğal olarak düşük tirajlı gazetelere hem reklam verme hem de yüksek reklam ücreti konusunda isteksiz davranılmaktadır (Şeker, 2007: 189).

Yerel basının dış etkenlere bağlı olarak karşılaştı̆̆ bir diğer sorun ise statüdür. Hizmet üreten işletme olmasından dolayı KOBİ (Küçük ve Orta Büyüklükte İşletme) kabul edilmesi gereken yerel basın (Özay, 2005: 16) bu statüye ancak 2009 yılında yapılan bir değişiklikle geçmiştir.

Yerel basın için insan kaynağı da önemli problemlerin başında gelmektedir. Normal şartlarda bünyesinde beyaz yakalı tabir edilen yazarlar ve muhabirler ile mavi yakalı olan matbaacıları barındırması gereken yerel basın (Akkaya, 2009: 47), ekonomik sorunlar nedeniyle hem yazı yazan hem de bu yazıların dağıtım işleriyle meşgul olan çalışanlar istihdam etmektedir. Yani gazete için içeriği hazırlayan kişi teknik süreçleri de gerçekleştirmekte, bazı durumlarda dağıtım ve satışı da aynı çalışanlar yapmaktadır. Bunun yanında BİK’ten resmi ilan ve reklam desteği alması için asgari kadro şartlarını yerine getirmesi gereken yerel gazeteler, naylon tabir edilen 
kadrolar oluşturmaktadır. Gazete sahibinin ailesi ve yakınlarının gazete çalışanı gibi gösterildiği bu durum nitelikli kadro oluşumunun önünde bir engel teşkil etmektedir.

Yerel basın kuruluşlarının kendi aralarındaki haksız rekabet de önemli sorunlar arasında yer almaktadır. Resmi ilan ve reklamların dışındaki ilanlar için gazetelerin kendi aralarındaki haksız rekabeti (daha düşük fiyata reklam yayınlama) reklam kaynaklarının etkin kullanılmamasının yanı sıra gazetelerin kendi imajlarına da büyük zarar vermektedir. Haksız rekabete bağlı olarak yaşanan bir diğer sorun da korsan/gecekondu gazetelerdir (Arslan, 2010: 260). Özellikle seçim dönemlerinde çıkan bazı yerel gazeteler, sektörde haksız rekabete neden olurken, okurların nezdinde yerel gazetelere olumsuz bir algı yüklemektedir. Rekabete dayalı olarak yerel gazetelerdeki haber ve köşe yazılarında yaşanan kavgalar da bu kuruluşların saygınlığını zedelemektedir (Kiracı, 1998: 75-76).

Yukarıda ifade edilen sorunların bir sonucu olarak yerel basının markalaşması mümkün olmamaktadır. Oysa bilgi ve iletişim teknolojilerinin sağlamış olduğu altyapı ile küreselleşen dünyada yerel basın için firsatlar söz konusudur. Küreselleşmenin bir dinamiği olarak yerel değerlere ilginin artması, doğal olarak yerel basına büyük avantajlar sunmaktadır (Bilgiç, 2004: 21). Ancak yerel basın küresel dünyada özgünlügünü korumak yerine yaygın basını örnek almakta (Demirkent, 1999: 75), onlara benzemeye çalışmaktadır. Küresel iletişim ortamının neden olduğu aynılaşma içerisinde yerelliğin de bulunduğu özgün yapıları tehdit etmektedir. Kutlu da (2008: 97-99) benzeşme sendromunu 'marka' ve 'imza' imgeleri üzerinden örnekle açıklamaktadır. Yazara göre marka umumi/kamusal bir nitelik taşımakta, imza ise hususi/özel bir yapı arz etmektedir. Yerel basının yaygın basına benzemeye çalışması özgünlüğünü arka plana itmekte, hegemonik bir yapı arz eden yaygın basının bir benzeri/temsili haline gelmektedir. Yerel basın bulunduğu coğrafyanın kimliğini yansıtan özgün yayınlar yerine yaygın basına benzemeye çalışmaktadır (Altunbaş, 2001: 154). Yerel basın ile yaygın basın arasındaki farkı 'organik' ve 'hormonlu' domates üzerinden anlatan Arslan da (2010: 256-257) hormonlu domatesin dış görüntüsünün mükemmelliğine karşın insan sağlığına zarar verdiğini anlatmakta, buna karşın organik domatesin ise albenisi olmamasına rağmen kendine has kokusu ve emekle üretilmiş olmanın verdiği lezzetle insan sağlığı için 
faydalı olduğunu söylemektedir. Arslan, yerel basının tıpkı organik domates gibi şeklinin bozukluğu, albenisinin olmamasına rağmen kendine has içerikleriyle hormonlu domates gibi olup görüntüsü mükemmel olan yaygın basına göre çok daha değerli olduğunu ifade etmektedir.

\section{Bilgi ve İletişim Teknolojileri Ekseninde Yerel Basının Geleceği}

İnternet, sosyal medya, mobil iletişim başta olmak üzere bilgi ve iletişim teknolojilerinde yaşanan gelişmeler, geleneksel olarak ifade bulan basılı gazeteciliği etkilemiştir. Yazılı dönem (haber mektupları) ve basılı dönemin (matbaada basılan yayınlar) ardından gelen dijital dönem (internet yayınları) büyük dönüşümleri getirmiş, gazetecilik sektörünü de bu değişime zorlamıştır. Basın sektörünü etkileyen bilgi ve iletişim teknolojileri, haber üretimi ve içeriğin çeşitli formlarının sergilenmesinde yeni yöntemler getirmiştir. Haberi üretip dağıtımını gerçekleştiren basın sektöründe olduğu kadar haberin tüketicisi olan bireylerin de teknoloji içerimli araçlarla yöndeşmesi/bütünleşmesi bu değişimi zorunlu kılmıştır. Ayrıca basın sektörü üzerinden hedef kitleye yönelik tercih/kanaat oluşturmada kullanılan reklam sektörü de bilgi ve iletişim teknolojileriyle uyumlanma sürecini hızlandırmıştır. Basın sektörü için geleneksel okuyucunun yanında yeni teknolojik altyapılarıyla yeni kullanıcılara ulaşmak, böylece hedef kitleyi genişleterek reklam pastasında pay sahibi olabilmenin yolu bilgi ve iletişim teknolojilerini kullanma ve yeniliklere uyarlanmayla mümkün hale gelmiştir. Her şeyden öte dijitalleşen dünyada basın sektörünün ayakta kalabilmesinin yolu da dönüşüme ayak uydurmaktan geçmektedir.

Basın sektörünün bilgi ve iletişim teknolojileri ekseninde dönüşümü birkaç adımda gerçekleşmiştir. İlk olarak dijitalleşmeyi mümkün kılan bilgisayarların basın sektöründe kullanımıyla analogdan dijitale geçiş, ardından ağı/çevrimiçi ortama mümkün kılan internet ve son olarak da internetin sunmuş olduğu yeni platformlar olarak sosyal formlar/uygulamalar ile mobil iletişim olanakları gelmektedir. Dijital dönüşüm süreci olarak bu geçişi ayrıntılandırmak gerekirse, bilgi ve iletişim teknolojileri basın sektöründe ilk olarak bilgisayarlar üzerinden bilgi depolama ve iş gücüne katkılar sunmuş, ikinci aşamada üretilen içeriğin basılı formla birlikte dijital olarak okuyucuya aktarılması sağlanmış ve son aşamada ise dijital ortamda yayılma politikaları hayata geçirilmiştir. Bu sayede zamana ve uzama bağlı olmayan haber 
akışı, hızlılık, çeşitlilik ve erişim kolaylığ 1 ile tanımlanan yeni bir gazetecilik anlayışı ortaya çıkmıştır. Dijital yayıncılığın aşama aşama basım ve yayın alanında hâkimiyetini kurduğu bu süreç, geleneksel tekniklerin yerini dijital tekniklerin aldığı bir dönüşüme işaret etmektedir (Binatl1, 2011: 18). Haber üretimi, içeriğin düzenlenmesi ve dağıtım aşamasına kadar her safhada bu dönüşüm en üst düzeyde yaşanmaktadır (Sütçü, 2014: 924). Geleneksel yayıncılık anlayışına göre dijital platformlar sermayeye ihtiyaç duyan basın sektörü için ucuz olması nedeniyle de tercih nedeni olmuştur. Habercilik üretimi açısından bilgi ve iletişim teknolojileri tek kişilik muhabirliği mümkün hale getirmiş, üstelik gazetecilerin olayı iletmesi için en etkili yöntemleri de sağlamıştır (Pavlik, 2013: 176-178). Haber toplama kadar haber kaynağına ulaşma ve gazetecilerin haberdar edilme yöntemleri de dönüşmüştür. Dijital platformlardan gönderilmiş iletiler, yazışmalar haber kaynakları arasına girmiştir. Basın sektöründe iş akışının yanı sıra gazetecilerin çalışma biçimleri de değişmiş, haberci ile haber kaynağı arasındaki yüz yüze iletişim dijital aracılı yöntemlerle çeşitlenmiştir (Törenli, 2005: 199).

Bilgi ve iletişim teknolojileri bağlamlı gazetecilik (Pavlik, 2013: 10-38) biçimi olarak yeni haber formlarına imkân sunmuştur. İletişim yöntemlerinin genişliği, hipermedya, yüksek okuyucu kitlesinin katılımı, dinamik içerik ve uyarlama olmak üzere beş boyutu bulunan bağlamlı gazetecilik, haberlerin daha etkili sunumunu ve hedef kitlenin de haberle ilişkisinin derinleşmesini sağlamaktadır.

Teknolojik gelişmelerin basın sektöründeki etkilerine rağmen haber içeriğinin önemi daha da artmıştır. Çünkü bilgi ve iletişim teknolojileriyle birlikte içerik ortamları zenginleşmiş, ancak beraberinde üretilen içeriğin çoğalması değil benzerleşmesi söz konusu olmuştur. Yani yayın imkânlarının gelişmesine, çeşitlenmesine rağmen yayın içeriğinin farklılaşması mümkün olmamıştır. Böylesi yayıncılık ortamında dağıtımı yapılacak içeriğin diğerlerinden farklılaşması büyük avantajlar sunmaktadır (Handley ve Chapman, 2013: 35-37). İçeriğin bu denli önemli ve avantaj sunduğu günümüzde yerel basının doğal olarak özgün içeriğe sahip olması en büyük artıları olmuştur. Ancak yerel basının bu konuda yeterince bilinç düzeyine sahip olmadığı görülmektedir. Yerel basın sahip olduğu özgün içeriği bilgi ve iletişim teknolojilerinin sunmuş olduğu imkânlarla paylaşabilirse küresel medya ortamında 
önemli bir avantaj elde etmiş olacaktır. Türkiye özelinde sorunlu bir yapı arz eden yerel basının ayakta kalabilmesi ve geleceğe dönük öngörüleri bilgi ve iletişim teknolojileri temelinde hayata geçebilecektir.

Yerel basının geleceğine dönük öngörüler genel olarak basılı gazeteciliğin geleceği üzerinden yapılmaktadır. Çünkü bilgi ve iletişim teknolojilerinin kullanıma girmesi ve her geçen gün yaygınlaşmasıyla birlikte basılı yayıncılık/gazetecilik etkisini yitirmektedir. Özellikle de okuyucuların çevrimiçi dolayımlı iletişim biçimlerine yönelmesi ve kullanılan teknolojilerin yaygınlaşmasıyla birlikte gazetecilik sektörü doğal olarak dijital ortama yönelmiş ve varlık gösterme biçimleri (internet sitesi, sosyal medya hesapları, mobil uygulamalar) hayata geçirmişlerdir. Özellikle de Amerika ve Batılı ülkelerde basılı yayıncılığa yapılan yatırımların dijital ortama kaydırılması, basılı gazetelerin çevrimiçi ortamda hayatına devam etmeye başlaması Türkiye'yi de etkisi altına almıştır. Türkiye'de ilk olarak Radikal gazetesi ${ }^{2}$ basılı yayıncılığa 2014 yılında son verip internet üzerinden okurlarıyla buluşmaya devam etmiştir. 5 Temmuz 2018 tarihinde ise bu kez Habertürk gazetesi ${ }^{3}$ basılı versiyonuna son vermiş ve internet üzerinden gazetecilik faaliyetini devam ettirmeyi sürdürmüştür. 2018 yılının Kasım ayı itibariyle de Vatan gazetesi ${ }^{4}$ baskısını $^{2}$ sonlandırmıştır. Türkiye'de yaygın basında 4 yıl içerisinde 3 önemli gazetenin baskısına son vermesi basılı gazeteciliğin geleceğine dönük olarak tartışmaları artırmıştır.

Basılı gazeteciliğin geleceği konusundaki tartışmalar özellikle Batıda yıllar öncesinden başlamıştır. Bu konuda beyan edilen fikirler basılı gazeteciliğin zorunlu olarak biteceği, ancak gazetecilik sektörünün de yayıncılık açısından dönüşeceğini ifade etmektedirler.

\footnotetext{
${ }^{2} 13$ Ekim 1996'da yayın hayatına başlayan Radikal gazetesi 21 Haziran 2014 tarihi itibariyle basılı yayınını sona erdirmiştir. www.radikal.com.tr internet sitesi de 4 Nisan 2016 yılına kadar yayınlarına devam etmiştir. Gazete 18 yılık basılı yayıncılık sürecinde 20-25 bin tiraja sahip olmuştur.

${ }^{3} 1$ Mart 2009 tarihinde yayın hayatına başlayan Habertürk gazetesi, tabloid boyutuyla okurlara sunulmuştur. Gazete, basılı yayınını durdurduğu 2018 yılında ortalama 200 bin tirajıyla en fazla satan ilk 5 gazete arasında yer almıştır. Gazetenin basılı versiyonunu sonlandırmasına neden olarak reklamların azalması ve baskı maliyetlerinin yüksek olması gösterilmiştir. Gazetenin internet sitesi www.haberturk.com yayına devam etmektedir.

${ }^{4} 2002$ yılında yayın hayatına başlayan Vatan gazetesi de 1 Kasım 2018 tarihi itibariyle baskısını sonlandırmıştır. Gazetenin internet sitesi www.gazetevatan.comyayınına devam etmektedir.
} 
TÜİK'in Yazılı Medya İstatistiklerine göre, hem basılı gazete sayısı hem de gazetelerin tirajı her yıl düşüş göstermektedir.

Tablo 1. Gazetelerin Yıllara Göre Sayısı(2013-2017)

$\begin{array}{llllllrl}\text { Yıl } & \text { Toplam } & \text { Yerel } & \text { (\%) } & \text { Bölgesel } & \text { (\%) } & \text { Yaygın } & \text { (\%) } \\ \mathbf{2 0 1 3} & 3100 & 2813 & 90,7 & 107 & 3,5 & 180 & 5,8 \\ \mathbf{2 0 1 4} & 2944 & 2619 & 89,0 & 143 & 4,9 & 182 & 6,2 \\ \mathbf{2 0 1 5} & 2731 & 2447 & 89,6 & 112 & 4,1 & 172 & 6,3 \\ \mathbf{2 0 1 6} & 2527 & 2293 & 90,7 & 66 & 2,6 & 168 & 6,6 \\ \mathbf{2 0 1 7} & 2474 & 2247 & 90,8 & 51 & 2,1 & 176 & 7,1\end{array}$

Kaynak: (TÜIK, 2018)

Tablolarda da görüldüğü üzere 2013 yılında 3100 olan gazete sayıs1 2017 yılında 2474'e düşmüştür. Yazılı basının yüzde 90,8'lik kısmına denk gelen yerel basını oluşturan gazete sayısı da 2013 yılında 2813 iken, bu sayı 2017 yılında 2247'ye düşmüştür.

Tablo 2. Gazetelerin Yıllara Göre Tirajı (2013-2017)

\begin{tabular}{llllllll} 
Yıl & Toplam & Yerel & $\mathbf{( \% )}$ & Bölgesel & (\%) & Yaygın & (\%) \\
$\mathbf{2 0 1 3}$ & 2296382004 & 338106943 & 14,7 & 48779838 & 2,1 & 1909495223 & 83,2 \\
$\mathbf{2 0 1 4}$ & 2140621401 & 294883759 & 13,8 & 42270003 & 2,0 & 1803467639 & 84,2 \\
$\mathbf{2 0 1 5}$ & 1993576561 & 285440701 & 14,3 & 32134637 & 1,6 & 1676001223 & 84,1 \\
$\mathbf{2 0 1 6}$ & 1603803420 & 264153968 & 16,5 & 24570971 & 1,5 & 1315078481 & 82,0 \\
$\mathbf{2 0 1 7}$ & 1559452053 & 246262664 & 15,8 & 11055489 & 0,7 & 1302133900 & 83,5 \\
\multicolumn{2}{c}{ Kaynak: (TÜIK, 2018) } & & & & & &
\end{tabular}

2013 yılında 2 milyar 296 milyon olan gazete tirajları 2017 yılında 1 milyar 559 milyona düşmüştür. Yerel basını teşkil eden gazetelerin tirajlarındaki düşüş de dikkat çekicidir. 2013 yılında 338 milyonu aşan yerel gazete tiraj sayısı, 2017 yılında 246 milyona kadar düşmüştür. 4 yıl içerisinde tirajda yaşanan bu keskin düşüş yazılı basının geleceğine ilişkin olumsuz bir tabloyu yansıtmaktadır. Öte yandan her iki tabloyu karşılaştıracak olursak, sayı bakımından yüzde 90’1 teşkil eden yerel basın, tiraj bakımından yüzde 16'yı oluşturmaktadır (www.tuik.gov.tr, 2018). Bu rakamlar yerel basının yaygın basın karşısındaki etkisizliğini de göstermektedir. 
Reuters Gazetecilik Çalışmaları Enstitüsü 2019 Dijital Haberler Raporu'nun Türkiye bölümünde de basılı gazete ve dergilerin y1llı toplam tirajlarının 2013-2017 yılları arasında yüzde 33 düşüş sergilediği ifade edilmiştir. Bu arka plan göz önüne alınarak yakın gelecekte Habertürk ve Vatan gazetesinin dışında başka gazetelerin de kapanmasının sürpriz olmayacağı ifade edilmektedir. Raporda, gazetelerin basılı versiyonlarını kapatmalarındaki en önemli etken olarak reklam gelirlerindeki payların istikrarlı bir şekilde düşüşü ve ithal olan kağıt fiyatının yükselişi gösterilmektedir. Raporda ayrıca haberlere ulaşmada kullanılan araçlarda akıllı telefonların tercih edildiğine de dikkat çekilmektedir (Newman vd., 2019).

Basılı gazete tirajlarındaki istikrarlı düşüş reklam gelirlerinden alınan paya da yansımıştır. Reklam gelirlerinin 2000'den sonraki seyrine bakıldığında; gazete, dergi ve radyoların reklam paylarının giderek azaldığı görülmektedir. Buna karşılık dijital ortam, 2006'dan itibaren payını en hızlı artıran mecra olarak dikkat çekmektedir (Sözeri ve Güney, 2011: 44). Reklamcılar Derneği'nin verilerine göre, 2014 yılının ilk 6 ayında medya yatırımlarında televizyon ilk sırada yer alırken, en hızlı büyüyen mecra internet olmuştur. Yatırımların \%52'sini televizyon, \%19.40'ını basın, arama motoru reklamları dahil \%18.20'sini dijital, \%6.70'ini açık hava, \%2.20'sini radyo ve \%1.10’unu ise sinema reklamları oluşturmuştur (Reklamcılar Derneği, 2018).

Dünyada 2017 yılında dijital medya yatırımları ilk defa diğer tüm mecraların önüne geçmiştir. Üstelik 2018 yılında dijital medya yatırımları toplam medya yatırımları içerisindeki payını diğer mecralara göre daha da hızlı bir şekilde artırmıştır. Dünyada 2018 yılında medya yatırımlarının yüzde 41 'i dijital mecralara yapılırken, bu büyüme payını ağırlıklı olarak yazılı basın ve TV'den aldığı belirtilmektedir. 
Tablo 3. 2010 ve 2018 Yıllarında Türkiye'de Medya ve Reklam Yatırımları (Milyon TL)

\begin{tabular}{|c|c|c|c|c|c|}
\hline Yıllar & TV & Basın & Radyo & Sinema & Dijital \\
\hline $\mathbf{2 0 1 0}$ & 2.017 & 942 & 103 & 45 & 251 \\
\hline $\mathbf{2 0 1 8}$ & 3.563 & 780 & 269 & 89 & 2.385 \\
\hline
\end{tabular}

Kaynak:(Reklamcılar Derneği, 2018)

Türkiye'de, medya yatırımları ve reklam gelirlerinde dijital mecralara olan özel ilgi ve bunun sonucu olarak aktarılan yatırım ve reklam payı büyük bir gelişme arz etmektedir. $\mathrm{Bu}$ durumun doğal bir sonucu olarak gazeteler $\mathrm{ABD}$ ve $\mathrm{AB}$ ülkeleri örneğinde olduğu dijital ortama özel önem atfetmekte ve yatırımlarını bu alana kaydırmaktadır. Son dönemde ise basılı yayını durdurarak dijital ortamda gazetecilik faaliyetini sürdürmek için girişimde bulunulmuştur. Tablo 3'te 2010 yılı ve 2018 yılına ilişkin medya ve reklam yatırımları yer almaktadır. Tabloya göre, basın sektörüne yapılan medya ve reklam yatırımlarında düşüş yaşanmıştır. Diğer geleneksel mecralarda (tv, radyo ve sinema) ise artış olmakla birlikte dijital ortamla karşılaştırıldığında çok düşük kalmaktadır. Dijital medya sektöründeki artış 8 yıl zarfında 10 kat artış göstermiştir.

Basılı gazeteciliğin geleceğine ilişkin tablo bu denli karamsarlık gösterirken, çözüm dijital yayıncılıkta görülmektedir. 2014 yılında inovasyon raporu hazırlayan New York Times gazetesinin o dönem tirajı 1.25 milyon iken, çevrimiçi kullanıcı sayısı 30 milyon, mobil uygulamasını da 20 milyon kişi kullanmıştır. Gazetenin 11.3 milyon Twitter takipçisi sayısı ve 5.7 milyon Facebook takipçisi vardır. Raporda, dijital alanda yatırımların artırılması gerektiği vurgulanmıştır (New York Times, 2014: 3). İletişim alanında köklü raporlar hazırlayan PEW Araştırma Merkezi de gazetelerin dijital ortama geçişi noktasında yoğun çalışmalar olduğuna dikkat çekmekte ve gelecekte dijital medyanın sektöre tümüyle hakim olacağı öngörüsünde bulunmaktadır (Jurkowitz ve diğerleri, 2014: 2-4). Reuters Gazetecilik Araştırmaları Enstitüsü’nün 2014 Dijital Haber Raporu'nda dijital yayıncılığın geleceğinde mobil teknolojilerin belirleyici olacağı, yıllar itibariyle ortaya çıkan rakamlarla ifade edilmektedir (Newman ve Levy, 2014: 8-9). Enstitünün 2019 raporu da bu öngörüleri doğrular nitelikte sonuçlara ulaşmaktadır. 
2019 yılı Ocak ayı itibariyle dünya genelinde 7 milyar 600 milyonu aşkın insanın 5 milyardan fazlası telefon kullanmakta, 4,5 milyara yakın internet ve 3,5 milyara yakın aktif sosyal medya kullanıcısı bulunmaktadır. 82 milyonu aşkın nüfusa sahip Türkiye'de ise 59 milyon internet, 52 milyon da sosyal medya kullanıcısı bulunmaktadır. Türkiye' de insanlar ortalama 7 saati aşkın süreyi internette geçirmekte, 3 saate yakın da sosyal medya platformlarında gezinmektedir (www.wearesocial.com, 2019). Bu istatistiki veriler dijital yayıncılığın hayatın tam merkezinde kendine yer edindiğini göstermektedir. Yayıncılığın da bu dönüşümden payını alması için yasal düzenlemeler de yapılmaktadır. 2014 yılı Temmuz ayında TBMM Adalet Komisyonu'ndan geçen Basın Kanunu ve Bazı Kanunlarda Değişiklik Yapılmasına Dair Kanun Tasarısı'nın 2. Maddesiyle internet haber siteleri yasal zemine kavuşturulmaları amacıyla 5187 sayılı Basın Kanununun kapsamına alınmıştır. Böylece gazetelerin dijitale dönüşümü konusunda hukuki alt yap1 oluşturulmuştur. Kanun Tasarısının 14. Maddesi de internet haber sitelerinin resmi ilan almasının önünü açmıştır (www.tbmm.gov.tr, 2014).

PEW Araştırma Merkezi’nin ABD’ye yönelik hazırladığı dijital medya raporunda, bilgi ve iletişim teknolojilerinin sermaye altyapısı gerektirmemesi, zaman ve uzamın kısıtlılıklarını ortadan kaldırması nedeniyle yerel basın için önemli olduğuna dikkat çekilmektedir. Raporda, yerel haberlerin içerik boyutuyla dijital çağda güvenilirliği sağladığı vurgulanmıştır. Tüm bu nedenlerden dolayı yerel basının dijital ortama uyumu önemsenmektedir. Yerel basın kurumlarının kamuoyu katılımı, açıklık ve hesap verilebilirlik özellikleriyle demokrasiye hizmet ettiğine dikkat çekilen raporda, yerel basının dijital ortamda bu sorumluluklarını etkili bir şekilde yerine getireceği ifade edilmiştir (Jurkowitz vd., 2014: 3-5).

Bilgi ve iletişim teknolojilerinin etkisiyle küreselleşen dünyada yerel formların önemi de her geçen gün daha fazla hissedilmektedir. 'Global/küresel' ve 'lokal/yerel' kelimelerinin oluşturduğu 'Glokalleşme/glocalization' kavramı da küresel iletişim ortamında yerelliğin anahtar bir kelime olduğunu göstermektedir. Yerelliğin potansiyelini ortaya koyan bu yaklaşım, yatay ve dikey birleşmelerle küresel medya ortamındaki tekelleşmeye karşı yerel özgünlükleri sunarak yurttaş katılımı ve kamusal alanı güçlendiren yerel basını ön plana çıkarmaktadır (Güven, 
2007: 321).

Yukarıda ifade edilen tüm gelişmeler yerel basının önemini ortaya koymaktadır. $\mathrm{Bu}$ düşünceden hareketle Gümüşhane yerel basının genel durumu hakkında bilgi verilerek, geleceğe dönük öngörüler tartışılacaktır.

\section{Gümüşhane Yerel Basını}

Gümüşhane'nin matbuat/basın tarihi geçmişten bugüne şehirle özdeş bir tablo çizmiştir. Şehrin coğrafi, siyasi, ekonomik ve toplumsal yapısından kaynaklı olarak Gümüşhane basınının diğer şehir basın hareketlerine oranla daha zayıf kaldığını söylemek mümkündür. Gümüşhane basını üzerine bugüne kadar yapılmış akademik çalışmaların sadece bir yüksek lisans tezi (Çubukçu, 2016) ve bir makaleden (Saylan, 2013) ibaret olması, bu alanda çalışma yapma gerekliliğini göstermektedir. $\mathrm{Bu}$ çalışmanın temel hareket noktası da şehrin basın tarihini bütüncül bir yaklaşımla ele alarak mevcut durum analizini yapmanın ötesinde geleceğine ilişkin projeksiyonlar çizilmesi olmuştur. Ayrıca konuya ilişkin literatüre de katkı sağlanmış olacaktır.

\subsection{Gümüşhane'de Yayınlanan Gazeteler}

1922’de Ufuk gazetesiyle ilk basın hareketinin başladığı Gümüşhane'de o tarihten günümüze kadar ilçelerle birlikte 20'ye yakın yerel gazete 10'u aşkıı dergi yayınlanmıştır. Bugün ise Gümüşhane merkezinde 4 tanesi günlük, 1 tanesi haftalık olmak üzere aktif olarak yayımlanan 5 adet gazete, üniversite uygulama gazetesi ve radyosu ile bir dergi ve ulusal haber ajanslarının temsilcilikleri bulunmaktadır. Bilgi ve iletişim teknolojilerinin sunmuş olduğu imkânlarla birlikte ayrıca müstakil yerel internet haber siteleri de yayıncılık yapmaktadır. Tarihsel süreç izlenerek Gümüşhane'de yayınlanmış gazete ve dergilere ilişkin bilgiler ise şöyle:

Ufuk Gazetesi (1922-1923): 1922 tarihinde aylik olarak okuyucusuyla buluşan Ufuk gazetesini Meşrutiyet'in ikinci döneminde milletvekilliği yapmış olan Refioğullarından öğretmen Rıfkı Bey yayınlamıştır. Gazete ancak bir yıl yayınlanabilmiştir (Gümüşhane Valiliği, 1999: 24).

Gümüşeli Gazetesi (1927-1952): Gümüşhane'de ilk matbaa 1927 y1lında 
kurulmuştur. Gümüşeli adını taşıyan bu matbaada 25 Şubat 1929 yılında aynı isimle Gümüşeli Gazetesi ${ }^{5}$ yayınlanmaya başlanmıştır (Okay, 1938: 69). Gümüşhane İl Özel İdare Müdürlüğü tarafından yarı resmi bir nitelikte 4 sayfa ve haftalık (Pazartesi ya da Perşembe günleri, 1940 yılından sonra 15 günde bir yayınlandı) yayınlanan gazete şehrin vilayet gazetesi olma özelliğini taşımaktadır. Gümüşeli Gazetesi’nin sahibi olan Sabri Özcan San aynı zamanda Genel Yayın Yönetmenliğini yürütmüştür. Gazetede daha çok Gümüşhane Halkevi'nin faaliyetlerine yer verilmiş, bir anlamda Halkevi’nin yayın organı olma görevi üstlenmiştir (Fıçıcı, 2013: 69) İl Özel İdare Müdürlüğü, 1952 yılında gazetenin basıldığı matbaa ve diğer teknik ekipmanları satınca Gümüşheli Gazetesi'nin yayın hayatı sonlanmıştır.

Kelkit Gazetesi (1953-1954): 1953 yılında yayın hayatına başlayan gazete Erzincan'da basılmış ve kuruluşundan 7 ay sonra kapanmıştır. İrfani Doğan'ın sahibi olduğu gazete Nurettin Özdemir tarafından aylık olarak 4 sayfa şeklinde okuyucusuyla buluşmuştur.

Inkılabın Sesi (1960-1961): İhsan Karakelle'nin sorumlu müdürü olduğu gazete 27 Mayıs 1960 darbesinden sonra yayınlanmıştır. Bayburt'ta basılan gazete o dönem Bayburt Gümüşhane’nin ilçesi olduğu için künye olarak Gümüşhane merkezlidir. Gazete, kuruluşundan bir buçuk yıl sonra kapanmıştır (Gümüşhane İl Y1llı̆̆1, 1967: 183).

Kelkit Çayı (1979-1986): Aylık olarak yayın hayatına başlayan 4 sayfalık gazetenin Zeki Sözer'in sahipliğinde İsmail Hakkı Topuz’un yöneticiliğinde Erzincan'da basımı yapılmıştır. Gazete 7 yıllık bir yayıncılık hayıtının ardından kapanmıştır (Gümüşhane Valiliği, 1999: 169).

Gümüşhane'nin Sesi (1992-1994): Cavga Matbaası sahibi Mehmail Cavga tarafından 15 günde bir 4-6 sayfa olarak yayınlanan gazete Trabzon'da basılmıştır.

Gümüş Vadi (1993- ?): Ayten Şanlıtürk tarafından yayınlanmaya başlanan gazetenin sorumlu müdürlüğünü ise Hakan Şanlıtürk yapmıştır. Gazete, Trabzon’da

\footnotetext{
5 Gümüşeli gazetesinin 1934-1950 yılları arasında basılan nüshaları İstanbul Üniversitesi Beyazıt Kütüphanesi'nde bulunmaktadır. Gazetenin diğer nüshaları bulunmamaktadır. Gümüşhane’de dergiye ilişkin herhangi bir arşivin bulunmaması eksiklik olarak ifade edilebilir.
} 
basılmıştır.

Gümüş Belde (1992- ?): Dönemin Gümüşhane Belediye Başkanı Naim Ağaç tarafından gerekli görüldügünde yayınlanmış gazetenin dizgi ve baskısı ise Trabzon'da yapılmıştır (Gümüşhane Valiliği, 1999: 170).

Vilayet (1992-?): Gümüşhane Valiliği tarafından yayınlanan gazete ancak 3 sayı çıkabilmiştir. Gümüş Belde gazetesi gibi Vilayet gazetesi de gerektiğinde yayınlanmış, ardından yayını durdurulmuştur.

Gümüşhane Harşitin Sesi (2008-?): 2008 y1lında kurulan Gümüşhane Harşitin Sesi gazetesi 10 günde bir yayınlanmıştır.

Gümüş Haber (2013-?): 2013 yılında kurulan Gümüş Haber gazetesi haftalık olarak yayınlanmıştır (Özarslan vd., 2013: 348-352).

\subsection{Gümüşhane'de Yayınlanan Dergiler}

Gümüşhane'de ilk dergi 1924 yılında yayınlanmış, o tarihten 1990'lı yıllara kadar dergi yayını olmamıştır. 90'lı yıllarda yeniden filizlenen dergi yayıncılı̆̆ı ise süreklilik kazanamamış, dergilerin çoğunluğu birkaç sayı yayınlandıktan sonra kapanmış ya da kapanmak zorunda kalmıştır.

Irfan Yolunda ilk Adım Dergisi (1924): Gümüşhane'de 'İrfan Yolunda İlk Adım’ dergisinin ilk sayısı 15 Nisan 1924 tarihinde yayınlanmıştır. İmtiyaz sahibi lise müdürü Nizameddin, sorumlu müdürü ise Gümüşhane' deki ilk tedrisat müfettişi Trabzonlu Hüseyin Avni'dir. Derginin basımı Trabzon'da İkbal Matbaası'nda yapılmıştır. Hüseyin Avni, yazılarında derginin eğitim ve köylü dergisi olduğunu ifade etmiştir. 10 sayfa olarak ayda 2 kez yayınlanan dergi uzun ömürlü olmamış ve ancak 3 sayı çıkabilmiştir. Derginin sayıları 15 Nisan, 30 Nisan ve 31 Mayıs 1924 tarihlerinde çıkmıştır (Üçüncüoğlu vd., 2006: 70-71).

Beşinci Mevsim (1993-1994): İlk sayısı Mart 1993'te çıkan derginin sahibi Nazlı Koçoğlu, sorumlu müdürü ise Gülşen Yıldırım'dır. Sanat, edebiyat, eğitim ve diğer konularda yazıların yer aldı̆̆ı dergi 12. sayısının ardından yayın hayatına son vermiştir.

Genç Kalemler (1994-?): Mayıs 1994 tarihinde sahipliğini Mustafa Kars, yazı 
işleri müdürlüğünü ise Eyüp Yağlıdere'nin üstlendiği gazete ayda bir yayınlanmıştır.

Haber 29 (1993-?): Eylül 1993 tarihinde yayın hayatına başlayan derginin sahibi ve sorumlu müdürü Vedat Kolotoğlu'dur. Trabzon'da basılan dergi ilk 5 sayının ardından kapanmıştır.

Kültür Vadisi Gümüşhane (1994-2001): Dergi, Gümüşhane'yi sosyal, kültürel, ekonomik yönden tanıtmak amacıyla Gümüşhane Valiliği tarafından yayınlanmaya başlanmıştır. Üç ayda bir çıkan dergi Gümüşhanelilerle haberleşmek, Gümüşhane'yi sosyal, kültürel, ekonomik yönden tanıtmak amacıyla, Gümüşhane İli Kültür Varlıklarını ve Sosyal Değerlerini Araştırma, Derleme, Koruma, Tanıtma ve Yayınlama Yönergesi gereğince yayınlanmıştır. 16 sayı yayınlanan dergi 2001 yılında kapanmıştır.

Harşit (2003-2004): Kültür sanat konusunda yayın yapan derginin olarak ilk sayısı Nisan 2003 'te çıkmıştır. Harşit dergisi, ilk sayılarında aylık olarak düzenli çıkmışsa da devamında iki ayda, bazen de aylar sonra çıkabilmiştir. Derginin, yazarları arasında Gümüşhane'de ikamet eden kültür, sanat ve edebiyat çevrelerinden kişiler (başta öğretmenler ve eğitim sektöründe çalışanlar) ve diğer illerdeki Gümüşhaneliler olmuştur. Dergide şiir, edebiyat yazıları, denemeler yer almıştır. Ancak 9 sayı yayınlanabilen dergi 2004 yılında maddi imkânsızlıklardan dolayı kapanmıştır.

Cümle (2006-2007): Harşit dergisinin ekonomik sebeplerle kapanmasının ardından bu derginin yayın kurulu tarafından yeni bir kültür, sanat ve edebiyat dergisi çıkartılmıştır. 2006 yılında ilk sayısı çıkan Cümle dergisi, daha kurumsallaşmış (özellikle de teknik boyutuyla) bir dergi olarak yılda dört kez (kış, bahar, yaz ve güz olmak üzere) yayınlanmıştır. Sahibi Bayram Karabulut, Yazı İşleri Müdürü Yusuf Özgün olan dergi de ancak 5 sayı çıkabilmiş, sonrasında kapanmıştır. Her sayısı 7080 sayfa olan dergi Trabzon'da basılmıştır.

Cılga (2009-2010): Gümüşhane Dağcılık ve Doğa Sporları Kulübü yayını olarak ilk sayısı Mart 2009'da çıkmıştır. Sahibi Dursun Yücel, Genel Yayın Yönetmeni Niyazi Karabulut, Sorumlu Yazı İşleri Müdürü Mehmet Dede’dir. Dergi Trabzon’da Gündüz Matbaası'nda basılmıştır. Dergi, edebiyat ve gezi yazıları, köy 
tanıtımları, şiirler, Gümüşhane kültürüne ait olgular (yemekler, oyunlar gibi) olmak üzere zengin bir içeriğe sahiptir. Bu yönüyle dergi bir dernek dergisinden öte kültürel bir yayın özelliği taşımaktadır. Aylık olarak yayın hayatına başlayan dergi daha sonra üç ayda bir çıkmaya başlamıştır. Aralık 2010’da 13. sayıdan sonra kapanmıştır.

Herfene (2010- ....): Gümüşhane'de hem yayın periyodu hem de kurumsallaşma anlamında önde gelen dergi Herfene'dir. Sanat ve Düşünce Dergisi Herfene 2010 yılı kış döneminde yayın hayatına başlamıştır. Yılda dört kez (kış, bahar, yaz ve güz) çıkan derginin ilk sayısının künyesinde Sahibi; Gümüşhane Kültür Sanat Kulübü Adına Yusuf Dolan, Sorumlu Yazı İşleri Müdürü Sezai Köprülü ve yayın kurulunda ise şehrin edebiyat ve sanat camiasından önemli isimler yer almaktadır. Kendine ait yeri ve sitesi bulunan derginin tasarımı da kurumsal bir yapının (logosu ve mizanpajı) göstergesi olmuştur. Dergi kendini taşra dergisi olarak konumlandırmaktadır.

\section{5- Gümüşhane Yerel Basınının Bugünkü Durumu}

1922 tarihinde ilk yayınını okurlarıyla buluşturan Gümüşhane basını, uzun bir suskunluk döneminden sonra özellikle de 2000'li yılların ardından hem nitelik hem de nicelik açısından zenginleşmiştir. Bugün Gümüşhane'de günlük olarak yayınlanan 4 yerel gazete (Gümüşhane Olay, Gümüşkent, Gümüşkoza, Kuşakkaya), 1 haftalık gazete (Demokrat Gümüşhane), ilçelerde yayınlanan 4 haftalık gazete (Kelkit Gündem, Gümüşhane Ekspres, Köse'nin Sesi ve Şiran Gündem), bir tane dergi (Herfene), 4 tane internet haber sitesi (gumushane.gen.tr, haber29.net, yenigumushane.com, gumushanedenhaber.com) ayrıca üç tane haber ajansı temsilciliği (AA, DHA, İHA) ve bir tane de televizyon kanalı temsilciliği (TRT) bulunmaktadır. Bunların yanında Gümüşhane Üniversitesi İletişim Fakültesi uygulama birimi Medya Merkezi bünyesinde de gazete, radyo, dergi ve internet haber sitesi (Gifhaber, Kampüs FM, Dergif, Fragman, haber.gumushane.edu.tr) yayınlarını sürdürmektedir.

Demokrat Gümüşhane: 1952 yılından bugüne yayın hayatını sürdüren Demokrat Gümüşhane gazetesi, kurucusu Lütfullah Kantek’ten oğulları Ahmet ve Metin Kantek’e geçmiş, 1981 yılında ise Hüseyin Ergin tarafından satın alınmıştır. 
Haftada iki gün (Pazartesi ve Perşembe) olmak üzere yayın hayatına başlayan gazete, 2005 yılından günümüze haftada bir yayınlanmaktadır. Gazete günümüzde Hüseyin Ergin'in oğlu Suat Ergin tarafından yayınlanmaktadır. Siyah beyaz 4 sayfa ofset matbaada basılan gazete haberlerini ajanslardan sağlamaktadır. Gazetenin internet sitesi bulunmamakla birlikte, köşe yazıları gumushane.gen.tr üzerinden okurlarıyla buluşmaktadır.Bayi satışı olmayan gazete abonelik sistemiyle dağıtılmaktadır. Gazete, Gümüşhane'nin yanı sıra 25 ilde bulunan abonelerine gönderilmektedir.

Kuşakkaya Gazetesi: 20 Haziran 1967 tarihinde yayınlanmaya başlayan gazetenin kurucuları Turan Tuğlu ve Zühtü Çetinkaya'dır. Haftada 2 gün (Salı ve Cuma günü), 4 sayfa olarak yayın hayatına başlayan gazete, 10 yıllık bir süreçte haftalık olarak yayınlanmış, 1982 yılı başından itibaren günlük olarak okuyucusuyla buluşmaktadır (Kuran, 1990: 27). Gazete 2013 yılında el değiştirmiştir. Gazetenin imtiyaz sahibi aynı zamanda Gümüşhane Gazeteciler Cemiyeti Başkanı da olan Sezai Köprülü'dür. Gazetede yazı işleri müdürü, sayfa editörü ve 2 muhabir ile bir dağıtım personeli çalışmakta, bir tane İletişim Fakültesi mezunu çalışanı bulunmaktadır. Gazetenin kurucusu Turan Tuğlu da köşe yazarı olarak gazetede devam etmektedir. 10 sayfa olarak yayınlanan gazete ofset bask1 makinesiyle siyah beyaz olarak basılmaktadır. Gazete, www.kusakkaya.com.tr adlı site üzerinden internet yayıncılığını 2005 'ten beri sürdürmektedir. Gazetenin internet sitesinin güncellenmesi bazen günlerce yapılmamaktadır. ${ }^{6}$ Gazetenin sosyal medya hesapları mevcut ancak güncellemesi tıpkı internet sitesi gibi nadiren yapılmaktadır. Facebook’ta 2013 Şubat ayında hesabı açılan gazetenin 242 takipçisi (Haziran 2019) bulunmaktadır. Gazetede yayınlanan haberlerin paylaşıldığı sosyal medya hesabında 2013 Temmuz ayından itibaren herhangi bir paylaşımda bulunulmamıştır. Aynı şekilde 2013 yılında Twitter hesabı açan gazetenin 33 takip edeni bulunmaktadır. Gazetenin Twitter hesabında sadece iki paylaşım yapılmıştır. Ayrıca gazetenin internet sitesinde sosyal medya hesaplarına yönlendirici herhangi bir simge ya da bilgi söz konusu değildir.

Gümüşkoza Gazetesi: Haziran 2006 tarihinde yayın hayatına başlayan gazete Hüseyin Çelik tarafından kurulmuştur. Gazete, 12 sayfa siyah beyaz olarak ofset bask1

${ }^{6} 2019$ yılının Haziran ayında gazetenin internet sitesi incelenmiş, en son yüklemesi yapılan haberin bir ay önce eklemesinin yapıldığı görülmüştür. 
makinesinde basılmaktadır. Gümüşkoza gazetesi internet yayınını www.gumuskoza.com.tr adresi üzerinden yapmaktadır. Günlük olarak güncellenen internet sitesinde gazetede yayınlanan haberlere yer verilmektedir. Gazetenin sosyal medya hesapları bulunmakta ve etkin bir şekilde kullanmaktadır. Gazetenin Twitter hesabında birinci sayfa fotoğrafları ve haberler günlük olarak paylaşılmaktadır. 2018 Kasım ayında açılan Twitter hesabının 133 takipçisi bulunmakta ve bu hesap üzerinden 2022 paylaşım yapılmıştır. 323 takip edeni bulunan Facebook hesabında ise bulunmakla birlikte 2015 yılından bu yana paylaşım yapılmamaktadır. Gazetede biri İletişim Fakültesi mezunu 6 kişi çalışmaktadır.

Gümüşhane Olay Gazetesi: Kasım 2014 tarihinde yayın hayatına başlayan gazetenin kurucusu Bekir Bulut'tur. İletişim Fakültesi mezunu olan Bekir Bulut ile birlikte çalışanların çoğunluğunu İletişim Fakültesi mezunları oluşturmaktadır. 8 sayfası renkli 12 sayfa olarak yayınlanan gazete Trabzon'da basılmaktadır. Gazete www.gumushaneolay.com internet sitesinden yayın yapmaktadır. Gazetede yer alan haberlerin paylaşıldığı internet sitesinin güncellemesi haftada ya da iki haftada bir yapılmaktadır. Gazetenin internet sitesi gibi sosyal medya hesaplarının güncellenmesi de belli aralıklarla yapılmaktadır. Gazetenin Facebook hesabını 1833 kişi takip etmekte, Twitter hesabının ise 2131 takipçisi bulunmaktadır. Gazetenin internet sitesinde sosyal medya hesaplarına yönlendiren simgeler bulunmaktadır.

Gümüşkent Gazetesi: Ocak 2006 tarihinde Bayram Tunç tarafından kurulan gazete 8 sayfa ve siyah beyaz olarak ofset matbaada basılmaktadır. Gazetenin internet sitesi www.gumuskent.net güncellemesi yapılmamaktadır. Gazetenin 4 çalışanının 3’ü İletişim Fakültesi mezunudur.

GiF Haber Gazetesi: Gümüşhane Üniversitesi İletişim Fakültesi bünyesinde Medya Merkezi'nde akademisyenlerin danışmanlığında öğrenciler tarafindan uygulama gazetesi olarak 3 ayda bir yayınlanmaktadır. İlk dönemde 500 adet basılan 16 sayfalık gazete daha sonra 1500 adet basılmaya başlanmıştır. Gazete öğrencilerin yanı sıra üniversite personeline, kamu kuruluşlarına, diğer üniversitelerin iletişim fakültelerine ücretsiz olarak dağıtılmaktadır. Gazetenin PDF formatında bütün sayfaları haber.gumushane.edu.tr sitesinde paylaşılmaktadır. 
DERGiF (2016-....): İçeriğini özel haberlerin oluşturduğu dergi, Gümüşhane Üniversitesi İletişim Fakültesi uygulama birimi olan Medya Merkezi'nde akademisyenlerin danışmanlığında öğrenciler tarafından yayınlanmaktadır. İlk sayısı 2016 yılında yayınlanmış ve yılda bir kez okurlarıyla buluşmaktadır.

Fragman (2017- ....): Gümüşhane İletişim Fakültesi uygulama birimi Medya Merkezi bünyesinde yayın hayatına başlayan Fragman dergisinde öğrencilerin sinema konusunda yazılarına ve film analizlerine yer verilmektedir.

Gümüşhane Illçelerinde Yayınlanan Gazeteler: Gümüşhane şehir merkezinin yanı sıra ilçelerde de (Kelkit, Şiran, Köse, Torul, Kürtün) gazeteler yayınlanmaktadır. Kelkit'te 2003 y1lında kurulan 'Kelkit Gündem’, Köse’de 'Köse'nin Sesi’ ve Şiran’da da 2009 yılında kurulan 'Şiran Gündem' gazeteleri yayınlanmaktadır.

Gümüşhane'de Yayın Yapan Radyolar: Gümüşhane ilinde geçmiş yıllarda çeşitli adlarda radyolar kurulmasına rağmen, RTÜK'e yatırılması gereken harçların ödenmemesi nedeniyle 2006 yılında kapatılmıştır (Özarslan vd., 2013: 351). 2019 yılı itibariyle Gümüşhane'de İletişim Fakültesi uygulama birimi Medya Merkezi'nde Kampüs FM radyo yayınını sürdürmektedir. Kampüs FM'de öğrenciler tarafından hazırlanan haber, kültür, sanat ve müzik programları dinleyicilere ulaşmaktadır.

Haber Ajansları ve Gazete Temsilcilikleri: Gümüşhane'de Anadolu Ajansı başta olmak üzere İhlas Haber Ajansı ve Demirören Haber Ajansı'nın temsilcilikleri bulunmaktadır. Ayrıca TRT’nin temsilciliği de bulunmaktadır.

Internet Haber Siteleri: Gümüşhane merkez ve ilçelerde yayın yapan internet haber sitesi gazete sayısına göre oldukça fazladır. Tıpkı gazete ve dergilerde olduğu gibi internet haber sitelerinin de kurumsallaşma sorunu bulunmaktadır. Birkaç örneğin dışında yeni açılan internet haber siteleri kısa bir süre sonra kapanmış, bazı internet haber siteleri ise güncellenmemektedir. Haber sitelerinin nicelik açısından bu kadar fazla olmasının nedeni yayın maliyetinin düşük olması ve özelliklede farklı coğrafyalardaki hemşerilere seslenme olanağını sunmasıdır.

İnternet haber sitelerini tek tek incelemek mümkün olmayacağı için genel karakteristik özelliklerinden bahsettikten sonra, isimlerini yazmak yeterli olacaktır. Bu 
siteler; gumushane.gen.tr, gumuhanedenhaber.com, gündogumu.com, haber29.com, gumushane29.com, habergumus.com, gundem29.com, gumushaneexpres.com, yenigumushane.com, torulgundem.com, kelkithaber.tv, haberkelkit.com'dur. $\mathrm{Bu}$ haber sitelerinin içerisinde en fazla okuyucu kitlesine sahip olan gumushane.gen.tr sitesidir.

\section{DEĞERLENDIRME VE SONUÇ}

İletişim araçlarının gelişimi ve dönüşümünde en büyük etkiye sahip olan bilgi teknolojileri, üretim ve dağıtım sürecinde medya içeriğinin çeşitli formlarının sergilenmesinde en temel araç özelliği taşımaktadır. Türkiye'de ulusal basın arasında çok kısa bir sürede yayılan internet gazeteciliği, yapılan işin seyrini ve şeklini değiştirmesi ve getirdiği olanakların kullanılması bağlamında yerel basın için dikkat çekici bir noktayı teşkil etmektedir. İnternetin yaygınlaşmasıyla birlikte düşük maliyeti ve sunduğu imkânlar nedeniyle yerel basın, internet gazeteciliğini hayata geçirmeye başlamıştır. Özellikle de yerellik unsurunun internet ortamıyla birlikte dönüşmesi yerel gazeteciliği daha da önemli kılmıştır (Gürcan ve Bekiroğlu, 2007: 22). Ayrıca coğrafi ve kültürel sınırları ortadan kaldırarak ilgi duyulan ve erişim sınırlılığı olmayan, her habere ulaşmayı olanaklı kılan internet bu özellikleriyle yerel gazeteler açısından büyük önem taşımaktadır (Gürcan ve Bayram, 2005: 53).

Türkiye genelinde olduğu gibi Gümüşhane'de de yerel basın sorunlarla boğuşmaktadır. Bu sorunların kaynağında yer alan iç ve dış etkenlerin belirlenmesi önem arz etmektedir. Gümüşhane'de yerel basının sahiplik ve yönetim organizasyonu, gelir kaynakları ve giderleri, fiziki ve teknik altyapısı sorunlu algının oluşmasında öncelikli alanlardır. Devlet destekli olarak vilayet matbaalarıyla başlayan yerel gazetecilik serüveni, bugün Basın İlan Kurumu'nun aracılık etmiş olduğu resmi ilanlarla yerel gazetelerin ayakta kalmasını sağlamaktadır. Yukarıda ifade edilen sorunların çözümünde de devletin itici bir güç olarak yerel gazeteleri, basılı gazeteciliğin sonlandığı günümüz iletişim ortamında bilgi ve iletişim teknolojileri bazlı dijital dönüşüme hazır olma konusunda yasal altyapı ve ekonomik destek boyutuyla teşvik etmesi gerekmektedir. Bu sayede Yalçın'ın (2013: 80) ifade ettiği 'ulusal öykünme habercilik' yerine yerel gazeteler yayınlandıkları şehirlerin gündemini yakalayacaktır. Gümüşhane özeline baktığımızda devletin destekleyip 
teşvik ettiği yerel basında, Gümüşhane Üniversitesi İletişim Fakültesi’nin de öğrenci yetiştirerek sektöre kazandırmasıyla demokratik katılımcı bir yapı egemen olacaktır.

Çalışma kapsamında tarihsel süreciyle birlikte ele alınan Gümüşhane basınının geçmişten bugüne ortaya koyduğu yayıncılık serüveninin cılız kaldığı ve bugün de nitelik ve niceliksel olarak geçmişten daha iyi bir konumda olmasının rağmen, bilgi ve iletişim teknolojilerinin kullanımı noktasında iyi bir tablo ortaya koyamadığı görülmüştür. Gümüşhane basınını teşkil eden gazetelerin, basılı yayıncılığın geleceğine ilişkin karamsar tablodan etkilenmemesi için bilgi ve iletişim teknolojilerinin sunmuş olduğu avantajlardan faydalanması gerekmektedir.

Gümüşhane yerel basınına baktığımızda mevcut yayın yapan basılı gazetelerin çevrimiçi yayıncılığın önemini fark etmelerine rağmen, yerel basının bir kurum olarak iç ve dış etkenlerden kaynaklı sorunlarıyla baş başa kalmasından dolayı dijital dönüşüme hazır bir tablo sergileyememektedirler. Bazı gazetelerin internet sitesini hala hayata geçirememesi, bazılarının sitenin güncellenmesi konusunda başarılı bir örnek ortaya koyamaması, gazetelerin içinde bulundukları sorunlardan kaynaklı gösterilmektedir. Basılı gazeteye girmiş oldukları haberleri günü gününe çevrimiçi ortamda okuyucu ile buluşturma gibi bir kaygının Gümüşhane basını için geçerli olmadığını söylemek mümkünse de, devlet tarafından verilen resmi ilanların sadece basılı gazete için geçerli olması yerel gazetecileri sadece bu alanda teşvik etmeye yetmektedir. Aynı şekilde sosyal medya ve mobil iletişim teknolojileri için de olumsuz bir tablo söz konusu olmasına rağmen, çözümün devletin yerel basına dijital dönüşüm konusunda destek vermesi ve teşvik etmesinden geçtiği görülmektedir.

\section{KAYNAKÇA}

ALKAN, Ahmet Turan (1998). Yerel Gazetecilik, Televizyonculuk ve Radyoculukta Meslek İçi Eğitim. Yerel Basın Eğitim Seminerleri Dizisi: 8, Sivas: Konrad Adenauer Vakfı Yayınları,

ARSLAN, Mustafa (2010). Ne Haber, Ankara: Türkiye Gazeteciler Cemiyeti Yayınlar1. 
AYHAN, Bünyamin (2007). Osmanlı'dan Cumhuriyet'e Toplumsal Kimlik Oluşumunda Basının Rolü, (Editörler), Bilal Arık ve Mustafa Şeker. İletişim ve Ötesi, Konya: Tablet Yayınları. s: 259-305.

BAKOĞLU, Faik (1998). 1 Yerel Gazetecilik, Televizyonculuk ve Radyoculukta Meslek İçi Eğitim. Yerel Basın Eğitim Seminerleri Dizisi: 8, Sivas: Konrad Adenauer Vakfı Yayınları.

BODUR, Feyyaz (1996). Yerel Basında Yönetim ve Örgüt Yapısı, Anadolu Üniversitesi Sosyal Bilimler Enstitüsü Yayınlanmamış Doktora Tezi, Eskişehir.

CHARON, Jean-Marie (1992). Medya Dünyası, (Çev: O. Tatlıpınar), İstanbul: İletişim Yayınları.

CILGA Dergisi, Sayı 1, Mart 2009

Cumhuriyetin 75. Yılında Gümüşhane (1999). Gümüşhane: Gümüşhane Valiliği.

CÜMLE Dergisi, Güz 2006.

DERGİF, Gümüşhane Üniversitesi İletişim Fakültesi, Sayı 1, 2016.

ERDOĞAN, İrfan (2007). Türkiye'de Gazetecilik ve Bilim İletişimi. Ankara: Gazi Üniversitesi İletişim Fakültesi Yayınları.

ERINCÇ, Orhan (2007). Yerel Medyanın Tarihsel Gelişimi ve Geleceği, Türkiye'de Yerel Basın, İstanbul: İstanbul Üniversitesi İletişim Fakültesi Yayınları.

FIÇICI, Nazım (2013). Gümüşhane Halkevleri, Atatürk Üniversitesi Atatürk İlkeleri ve İnkılap Tarihi Enstitüsü Yüksek Lisans Tezi, Erzurum.

Gümüşhane İl Yıllığg (1967). Ankara: Balkanoğlu Matbaacılık.

GÜRELİ, Nail (1999). Yerel Televizyonculukta Meslek İçi Eğitim. Yerel Basın Eğitim Seminerleri Dizisi: 10, Van: Konrad Adenauer Vakfı Yayınları.

GÜVEN, Oğuzhan Özgür (2007). Küresel Medya-Yerelleşme ve Yerel Medya, Türkeye'de Yerel Basın, İstanbul: İstanbul Üniversitesi İletişim Fakültesi Yayınları.

Harşit Dergisi, Yı1 2, Sayı 8, Mayıs-Haziran 2004. 
JURKOWITZ, Mark;MITCHELL, Amy; PAGE, Dana (2014).The Growth in Digital Reporting. PEW Research Center http://www.journalism.org/files/2014/03/Shifts-in-Reporting_Foruploading.pdf, Erişim Tarihi: 28.11.2014.

KURAN, Ercüment (1990). Cumhuriyet Devrinde Gümüşhane'nin Sosyal, Ekonomik ve Kültürel Gelişmesi. Geçmişte ve Günümüzde Gümüşhane. Gümüşhane: Gümüşhane Valiliği, s.23-27.

KUYUCU, Michael (2012). Türkiye'de Medya Ekonomisi. İstanbul: Esen Kitap.

NEW YORK TIMES $\quad$ (2014). Innovation, www.presscouncil.org.au/uploads/52321/ufiles/The_New_York_Times_Inno vation_Report_-_March_2014.pdf., Erişim Tarihi: 05.04.2014.

NEWMAN, Nic:LEVY, David A. (2014). Reuters Institute Digital News Report 2014 Tracking the Future of News. https://reutersinstitute.politics.ox.ac.uk/sites/default/files/Reuters\%20Institute \%20Digital\%20News\%20Report\%202014.pdf, Erişim Tarihi: 25.06.2019.

NEWMAN, Nic; FLETCHER Richard; KALOGEROPOULOS, Antonis; NIELSEN, Rasmus Kleis (2019). Reuters Institute Digital News Report 2019, https://reutersinstitute.politics.ox.ac.uk/sites/default/files/2019-

06/DNR_2019_FINAL_1.pdf, Erişim Tarihi: 20.06.2019.

OKAY, Vehbi (1937). Cumhuriyetin 15. Yılında Gümüşhane, İstanbul: Ulus Basımevi.

ÖZARSLAN, Hüseyin; BOYNUKALIN, Neva, USTAKARA, Fuat; SARITAŞ, Ayşe; DUDU, Esra; ERBAŞ, Sefa (2013) Gümüşhane İlinde Tanıtım, Medya, Yerel Basın, Gümüşhane İli Swot Analizi, Gümüşhane: Gümüşhane Üniversitesi Yayınları.

ÖZER, Ömer (2012). Alternatif Medya, Alternatif Gazetecilik ve Joseph Pulitzer. Ö. Özer, Alternatif Medya Alternatif Gazetecilik, Konya: Literatürk Yayınları.

PAVLIK, John V. (2013) Dijital Teknoloji ve Gazetecilik: Demokrasiye Etkileri, Yeni Medya Üzerine..., (Çev. B. Kalsın), Konya: Literatürk Yayınları. 
Reklamcılar Derneği (2018). Medya Yatırımları, http://www.rd.org.tr/medyayatirimlari, Erişim Tarihi: 05.06. 2019.

SÖZERİ, Ceren; GÜNEY, Zeynep (2011). Türkiye'de Medyanın Ekonomi Politiği: Sektör Analizi. TESEV Yayınları. http://www.tesev.org.tr/assets/publications/file/19112013173118.pdf, Erişim Tarihi: 13 Nisan 2014.

TBMM, Basın Kanunu ve Bazı Kanunlarda Değişiklik Yapılmasına Dair Kanun Tasarısı ile Avrupa Birliği Uyum Komisyonu ve Adalet Komisyonu Raporu. http://www.tbmm.gov.tr/sirasayi/donem24/yi101/ss644.pdf. Erişim Tarihi: 20.04.2015.

TUNSTALL, Jeremy (1996). Newspaper Power: The New National Press in Britain. New York: Oxford University Press.

TÜİK (2018). Yazılı Medya İstatistikleri, http://www.tuik.gov.tr/PreHaberBultenleri.do?id=27605 (Erişim Tarihi: 25.06.2019.

Türkiye Cumhuriyeti'nin 75. Y1lında Gümüşhane (1999). Gümüşhane: Gümüşhane Valiliği.

ÜÇÜNCÜOĞLU, Güngör; KAHVECİ, Abdüllatif; KUTLU, Neslihan Altuntaş (2006). Gümüşhane M.Ö. 399-1937, Trabzon: Celepler Matbaas1.

YALÇIN, Aydın (2013). Şehir Tasavvuru, İstanbul: Akademi Basın Yayın.

YILMAZ, Hakan (2004). Yerel Basın Yerel Siyaset İlişkisi, Örnek: Akdeniz Atılım Gazetesi, İstanbul Üniversitesi Sosyal Bilimler Enstitüsü Yayınlanmamış Doktora Tezi, İstanbul. 